TARBIYATUNA: Kajian Pendidikan Islam

Volume 3 Nomor 2 Tahun 2019

Print ISSN : 2597-4807

Online ISSN : 2622-1942

\title{
IMPLEMENTASI STRATEGI INFORMATION SEARCH \\ DENGAN MEMAKSIMALKAN PENGGUNAAN SMARTPHONE \\ DALAM PEMBELAJARAN PAI KELAS X MIPA 1 \\ DI SMA NEGERI 1 GENTENG TAHUN PELAJARAN 2018/2019
}

\author{
Nur Laela Dewi ${ }^{1}$, Ahmad Izza Muttaqin ${ }^{2}$, Al Muftiyah ${ }^{3}$ \\ 1,2,3 Fakultas Tarbiyah, Institut Agama Islam Ibrahimy Genteng Banyuwangi \\ e-mail: 1dewinurlaela009@gmail.com ,2izza@iaiibrahimy.ac.id, \\ 3almuftiyah@iaiibrahimy.ac.id
}

\begin{abstract}
The learning strategy used by PAI educators or teachers at SMA Negeri 1 Genteng is an information search strategy using smartphones and utilizing wifi availability and smartphone ownership by students. This research use desciptive qualitative approach. In the process of collecting data using several techniques, namely observation, interview or interview, and documentation. Data analysis techniques using qualitative data analysis. Checking the validity of the data using source triangulation, this study uses a qualitative descriptive approach. Data collection uses techniques, observation, interview or interview, and documentation. Data analysis techniques using qualitative data analysis (data reduction, implementation, and drawing conclusions). Checking the validity of the data uses source triangulation. The application of this strategy to PAI learning is indeed able to optimize the use of smartphones as a learning medium and can increase student activity in learning with evidence that students are able to provide information related to memorization or presentations more smoothly. Supporting factors for this strategy are the availability of wifi networks in schools and smartphone ownership by each student, while for each obstacle that is the lack of enthusiasm of students, rowdy students and wifi networks that suddenly have problems, the PAI teacher has prepared solutions that can be used to overcome obstacles so that learning can still run as it should.
\end{abstract}

Keywords: Implementation, Information Search, Smartphone

\begin{tabular}{|c|c|c|}
\hline Accepted: & Reviewed: & Publised: \\
Juli 21 2019 & Agustus 23 2019 & September 30 2019 \\
\hline
\end{tabular}

\section{A. Pendahuluan}

Dalam dunia pendidikan baik di lingkup lembaga sekolah atau madrasah, proses pembelajaran memang hal yang wajib ada karena itu merupakan keharusan atau syarat dalam menciptakan proses pembelajaran. Dalam proses pembelajaran

This work is licensed under Creative Commons AttributionNon Commercial 4.0 International License Available iaiibrahimy.ac.id 
sendiri tidak luput dari penggunaan metode, model dan strategi yang harus dilakukan oleh pendidik sebagai cara yang harus digunakan untuk menambah efektifitas pembelajaran, baik pembelajaran umum maupun pembelajaran Pendidikan Agama Islam (PAI).

Pendidikan agama adalah salah satu dari tiga mata pelajaran yang wajib diberikan pada setiap jenis, jalur, dan jenjang pendidikan (pendidikan pancasila, pendidikan agama, pendidikan kewarganegaraan).“UU No. 2 Tahun 1989 Pasal 39 ayat (2). Diterangkan bahwa pendidikan agama merupakan usaha untuk memperkuat iman dan ketaqwaan terhadap Tuhan Yang Maha Esa sesuai dengan agama yang dianut oleh peserta didik" (Daulay, 2004 : 37)

Lebih lanjut dijelaskan bahwa peranan guru sangat penting dalam dunia pendidikan karena selain berperan mentransfer ilmu pengetahuan ke peserta didik, guru juga dituntut memberikan pendidikan karakter dan menjadi contoh karakter yang baik bagi anak didiknya. Guru mempunyai kewajiban-kewajiban yaitu merencanakan pembelajaran, melaksanakan proses pembelajaran yang bermutu, serta menilai dan mengevaluasi hasil pembelajaran dan meningkatkan dan mengembangkan kualifikasi akademik dan kompetensi secara berkelanjutan (Wijaya, $2018: 43$ )

Sebagai seorang pendidik profesional haruslah mempunyai ide-ide kreatif untuk menggunakan sebuah strategi yang bisa diterapkan pada peserta didiknya supaya mereka bisa lebih aktif dan kritis untuk mengemukakan pendapat dan pembelajaranpun bisa lebih efektif. Tuntutan sebagai pendidik yang kreatif haruslah punya strategi untuk menarik minat siswa atau peserta didik untuk ikut aktif dalam aktifitas belajar di kelas, pendidik harus mempunyai sifat hangat kepada siswanya serta memahami apa dan bagaimana pembelajaran yang menyenangkan bagi mereka. Salah satu faktor yang mempengaruhi kualitas pembelajaran adalah guru. Guru mempunyai pengaruh yang cukup dominan terhadap kualitas pembelajaran, karena gurulah yang bertanggung jawab terhadap proses pembelajaran di kelas (Waluyo, 2011 : 16). 
Di era yang sekarang ini teknologi semakin canggih dan berkembang seperti adanya Audio Visual, adanya internet, smartphone yang dimiliki setiap siswa dan masih banyak lagi media-media yang bisa dimanfaatkan atau dikolaborasikan dalam pembelajaran. Seperti halnya media smartphone yang dimiliki hampir setiap orang baik dari kalangan siswa maupun dari kalangan guru, akan tetapi smartphone cenderung digunakan hanya sebagai alat bermain game dan media untuk mengirim pesan saja bahkan dalam lingkup sekolah siswa cenderung menggunakan smartphone untuk bermain game yang didukung dengan adanya jaringan wifi milik sekolah baik di luar kelas maupun dalam proses pembelajaran. Ini adalah salah satu tugas dan juga tanggung jawab bagi seorang pendidik dalam menggunakan teknologi untuk diimplementasikan pada proses pembelajaran bukan hanya pada pembelajaran umum namun juga dalam pembelajaran PAI. Penggunaan media smartphone dalam proses pembelajaran PAI mempunyai manfaat sebagai penguat dalam penjelasan materi, mengingat bahwa materi PAI merupakan materi yang juga luas dan tidak akan efektif jika hanya disampaikan dengan metode ceramah atau penjelasan dengan teori saja, akan tetapi dengan ditampilkannya slide gambar atau video yang bisa diambil atau dicari di internet akan menjadi penguat penjelasan dan juga sebagai alat bantu bagi siswa untuk memahami materi tidak hanya dengan bayangan pemikiran saja. Dengan guru menjelaskan isi materi hanya dengan metode ceramah saja akan membuat siswa cenderung bosan dan hanya dapat memahami dengan bayangan dan gambaran dari pemikiran mereka masing-masing, karena tanpa adanya penggunaan mediamedia seperti tampilan gambar, video atau audio siswa akan lebih sulit untuk memahami materi yang diberikan oleh guru. Penerapan metode information search yang menggunakan media internet akan memberikan kemudahan bagi siswa untuk menemukan gambar-gambar, atau video yang berhubungan dengan materi yang diajarkan. Hal ini tentu akan mendukung pemikiran siswa menjadi lebih faham serta lebih cepat memahami materi. 
Adanya media internet dan jaringan wifi yang terdapat pada sekolahsekolah harus bisa digunakan sebagai kolaborasi metode, dengan mengaplikasikan salah satu strategi information search yang secara umum mengacu kepada bukubuku di perpustakaan akan tetapi strategi information search ini diterapkan mengacu pada jurnal PDF yang didapatkan dari internet dengan sumber yang bisa dipertanggung jawabkan keabsahannya maupun dijadikan sebagai media untuk menggunakan Audio Visual misalkan untuk mengunduh film tentang peperangan.

Van Meter dan Van Horn dalam Budi Winarno (2008:146-147) mendefinisikan implementasi sebagai tindakan-tindakan dalam keputusankeputusan sebelumnya. Tindakan-tindakan ini mencakup usaha-usaha untuk mengubah keputusan-keputusan menjadi tindakan-tindakan operasional dalam kurun waktu tertentu maupun dalam rangka melanjutkan usaha-usaha untuk mencapai perubahan besar dan kecil yang ditetapkan oleh keputusan-keputusan yang dilakukan oleh organisasi publik yang diarahkan untuk mencapai tujuantujuan yang telah ditetapkan.

Implementasi tidak akan dimulai sebelum tujuan-tujuan dan sasaransasaran ditetapkan atau diidentifikasi oleh sebuah keputusan. Jadi implementasi merupakan suatu proses kegiatan yang dilakukan oleh berbagai aktor sehingga pada akhirnya akan mendapatkan suatu hasil yang sesuai dengan tujuan-tujuan atau sasaran-sasaran itu sendiri.

Saud dalam Mulyono dan Wekke (2018:4) mengungkapkan bahwa upaya mewujudkan pembelajaran yang efektif sangat tergantung kepada bagaimana guru dapat mengembangkan strategi pembelajaran, serta dapat memilih strategi yang tepat dalam kegiatan pembelajaran. Lembaga sekolah umum tetap mengajarkan pembelajaran agama dalam setiap proses belajar mengajar hal ini dikarenakan dari pemerintah yaitu Direktur Jendral Pendidikan Islam Kementerian Agama RI Kamarruddin Amin mengatakan bahwa diajarkannya pelajaran pendidikan agama di sekolah mempunyai dua tujuan, yaitu Pertama membentuk pribadi yang saleh 
dan bertaqwa kepada Tuhan. Kedua, bagaimana (pendidikan agama) bisa menjadi instrumen perekat sosial, memperkuat nasionalisme.

Pendidikan agama adalah salah satu dari tiga mata pelajaran yang wajib diberikan pada setiap jenis, jalur, dan jenjang pendidikan (pendidikan pancasila, pendidikan agama, pendidikan kewarganegaraan). “SISDIKNAS No. 2 Tahun 1989 Pasal 39 ayat (2), diterangkan bahwa pendidikan agama merupakan usaha untuk memperkuat iman dan ketaqwaan terhadap Tuhan Yang Maha Esa sesuai dengan agama yang dianut oleh peserta didik (Daulay, 2004 : 37).

Guru mempunyai kewajiban-kewajiban yaitu merencanakan pembelajaran, melaksanakan proses pembelajaran yang bermutu, serta menilai dan mengevaluasi hasil pembelajaran dan meningkatkan dan mengembangkan kualifikasi akademik dan kompetensi secara berkelanjutan (Wijaya, 2018 : 43). Tuntutan sebagai pendidik yang kreatif haruslah punya strategi untuk menarik minat siswa atau peserta didik untuk ikut aktif dalam aktifitas belajar di kelas. Salah satu faktor yang mempengaruhi kualitas pembelajaran adalah guru. Guru mempunyai pengaruh yang cukup dominan terhadap kualitas pembelajaran, karena gurulah yang bertanggung jawab terhadap proses pembelajaran di kelas (Waluyo, 2011 : 16).

Seperti pada salah satu sekolah di Banyuwangi dan di daerah Genteng tepatnya yaitu sekolah SMA Negeri 1 Genteng yang menggunakan internet dan smartphone sebagai salah satu media pembelajaran yang digunakan untuk menonton video dari film-film peperangan dalam materi SKI yang nantinya akan dipresentasikan di depan kelas. Pembelajaran pendidikan agama Islam adalah satu mata pelajaran yang diwajibkan dalam setiap lembaga sekolah, dan materi yang terdapat di dalamnya adalah sebagai pembimbing bagi kepribadian siswa, sedangkan secara umum dalam pembelajaran pendidikan agama Islam pendidik hanya menjelaskan isi materi dalam bentuk teori dan metode ceramah saja, hal ini menjadi suatu permasalahan di mana siswa minim ketertarikan terhadap pembelajaran PAI, guru yang berperan sebagai pendidik mempunyai tanggung 
jawab untuk menarik minat siswa supaya tertarik pada pendidikan agama Islam dengan strategi-strategi menarik pula, strategi yang diterapkan oleh guru haruslah strategi yang mempunyai daya tarik terhadap siswa dan juga mempunyai manfaat untuk melatih pemikiran siswa menjadi lebih kritis lagi.

Media smartphone yang dimiliki hampir setiap orang baik dari kalangan siswa maupun dari kalangan guru. Penggunaan media smartphone dalam proses pembelajaran PAI mempunyai manfaat sebagai penguat dalam penjelasan materi, mengingat bahwa materi PAI merupakan materi yang juga luas dan tidak akan efektif jika hanya disampaikan dengan metode ceramah atau penjelasan dengan teori saja, akan tetapi dengan ditampilkannya slide gambar atau video yang bisa diambil atau dicari di internet akan menjadi penguat penjelasan dan juga sebagai alat bantu bagi siswa untuk memahami materi tidak hanya dengan bayangan pemikiran saja. Penerapan metode information search yang menggunakan media internet akan memberikan kemudahan bagi siswa untuk menemukan gambargambar, atau video yang berhubungan dengan materi yang diajarkan.

Menurut Burahman dalam Pamungkas (2014 : 7) Information Search merupakan suatu strategi pembelajaran mencari informasi. Informasi dapat diperoleh melalui koran, buku paket, majalah atau internet. Hal tersebut digunakan agar siswa dapat memiliki informasi maka guru membuat suatu permasalahan yang dituangkan dalam lembar diskusi siswa. Pencarian informasi ini dilakukan secara kelompok yang bertujuan agar permasalahan tersebut terselesaikan dengan cepat dan apabila siswa malu bertanya kepada guru sehingga siswa dapat bertanya dengan teman sekelompoknya, sehingga terjadi tukar pendapat antar kelompok.

SMA Negeri 1 Genteng salah satu sekolah mengizinkan para siswa untuk membawa dan menggunakan smartphone ke sekolah serta menyediakan jaringan wifi yang memang di khususkan untuk siswa, dalam sebuah wawancara singkat peneliti dengan guru pengampu PAI, dalam sekolah tersebut memang mengizinkan siswa membawa smartphone dan juga terdapat pemebalajaran yang 
memanfaatkan smartphone sebagai media pemebelajaran khususnya dalam pembelajaran PAI karena mengingat yang dibutuhkan oleh peserta didik di zaman ini adalah pembelajaran yang menyenangkan dan metode-metode baru yang menggugah semangat mereka untuk mengikuti aktifitas belajar. Dengan latar belakang tersebut peneliti tertarik untuk meneliti terkait penggunaan smartphone sebagai media pembelajaran.

\section{B. Metode Penelitian}

Penelitian ini merupakan penelitian kualitatif jenis deskriptif kualitatif. Penelitian ini dilakukan pada bulan April sampai dengan bulan Juni 2019. Subyek penelitian adalah siswa dan siswi kelas X MIPA 1 SMA Negeri 1 Genteng. Teknik pengumpulan data menggunakan observasi, wawancara dan dokumentasi. Observasi digunakan untuk memperoleh data penelitian selama proses pembelajaran berlangsung yang dilakukan oleh guru pendidikan agama Islam.

Analisa data yang digunakan yaitu perencanaan, tindakan, pengamatan, refleksi. Pengumpulan data dalam penelitian ini menggunakan Triangulasi sumber, dimana data diperoleh dari tiga sumber yaitu : Kepala Sekolah, Guru PAI, Siswa kelas X MIPA 1 yang nantinya data tersebut akan dihubungkan dan disinkronkan.

\section{Hasil dan Pembahasan}

Setelah ditemukan data yang diperlukan dalam penelitian ini, baik dari hasil penelitian dengan Observasi, Wawancara dan Dokumentasi maka peneliti akan menganalisis dari hasil temuan dan menjelaskan penerapan strategi information search dengan mengoptimalkan penggunaan smartphone dalam pembelajaran PAI pada kelas X MIPA 1 di SMA Negeri 1 Genteng.

1. Pengimplementasian strategi information search dengan mengoptimalkan penggunaan informas dalam pembelajaran PAI kelas X MIPA 1 di SMA Negeri 1 Genteng.

Dalam setiap pembelajaran dan proses pembelajaran baik yang berlangsung di dalam kelas maupun di luar kelas tidak pernah lepas dari yang namanya penggunaan sebuah metode, dimana metode atau strategi ini adalah salah satu cara yang di gunakan guru atau pendidik dalam melancarkan proses 
penyampaikan serta mentransfer ilmu kepada para siswa siswi atau peserta didik. Penerapan sebuah stratgei bertujuan khusus untuk mempermudah siswa dalam memahami serta menerima pembelajaran yang diberikan guru, tidak hanya satu strategi saja yang digunakan guru namun juga berbagai metode-metode yang di dalamnya terdapat sebuah rancangan agar proses penyampaian pembelajaran menjadi lebih menyenangkan dan menarik bagi siswa.

Berdasarkan hasil wawancara peneliti dengan Bpk. Sunyoto Edy Santoso, S.Pd M.Pd selaku kepala sekolah SMA Negeri 1 Genteng pada tanggal 24 April 2019 lalu, Beliau memaparkan bahwa terkait peran kepala sekolah dalam menindak lanjuti keaktifan siswa dalam aktifitas belajar tentu sangat penting, dimana kepala sekolah memberikan arahan khususnya kepada pendidik untuk bisa memberikan metode-metode serta strategi yang berbeda yang dapat memberikan daya tarik kepada siswa untuk memberikan semangat baru dalam memahami sebuah penjelasan materi baik dalam mata pelajaran umum maupun keagamaan.

Terkait dengan penerapan strategi information search dengan menggunakan smartphone yang diterapkan guru kepada siswa dalam pembelajaran PAI, kepala sekolah sangat mengapresiasi dan mendukung adanya strategi ini, mengingat teknologi tentu juga dapat menjadi peran penting dalam mencari informasi terkait pembelajaran. Hal ini disampaikan dalam wawancara peneliti dengan kepala sekolah pada tanggal 24 April 2019, beliau menyampaikan pendapatnya terkait penerapan strategi ini: bahwa penerapan strategi information search dengan mengoptimalkan penggunaan smartphone sangat baik sekali, dimana siswa dapat lebih optimal dalam menggunakan handphone mereka sebagai sarana pembelajaran. Akan tetapi banyak hal yang juga perlu diperhatikan dalam penerapan strategi information search ini, salah satunya pendidik atau guru harus lebih teliti dalam mengkondisikan siswa saat proses belajar mengajar, karena kembali pada salah satu kekurangan strategi information search yaitu siswa akan mudah gaduh dengan kelompoknya masing-masing, dari hal ini maka peneraan strategi information seacrh dengan mengoptimalkan penggunaan smartphone juga 
menuntut guru untuk bisa mengkondisikan kelas atau siswa supaya proses pembelajaran bisa berjalan dengan lancar.

Dengan adanya media yang berjalur pada internet tentunya juga punya banyak manfaat jika diaplikasikan ke dalam dunia pembelajaran, misalkan dalam penerapan strategi information search pendidik mempunyai tujuan yang cukup penting yakni bagaimana proses pembelajaran tetap menggunakan metode ajar yang umum namun juga di kaitkan dengan era baru seperti sudah tersedianya internet, mengingat di zaman ini siswa atau siswi tidak luput dengan adanya gadget dimana terkadang mereka cenderung menggunakan gadget mereka hanya untuk sesuatu yang kurang bermanfaat, dari sini sebagai seorang guru atau pendidik harus mempunyai ide-ide yang kreatif untuk memberikan serta menerapkan sebuah metode modern yang memanfaatkan kepemilikan gadget pada siswa.

Implementasi strategi information search guna mengoptimalkan penggunaan smartphone, khususnya dalam pembelajaran PAI siswa dapat mengacukan materi pada jurnal-jurnal atau dokumen yang berbentuk PDF, memberikan rangkuman terhadap sebuah tampilan video-video film peperangan ataupun memberikan presentasi terkait tugas yang diberikan guru pada setiap kelompok siswa. Terkait hal ini juga di sampaikan oleh guru PAI SMA Negeri 1 Genteng yaitu Bpk. Lukman Hadi, S.Pd.I dalam wawancara pada tanggal 24 April 2019, peneliti dapat menyimpulkan bahwa implementasi strategi information search memang cocok diterapkan dalam pembelajaran PAI, mengingat adanya media internet yang menjadi pendukung diterapkannya strategi ini. Jika kembali pada peran guru yang harus menjadi seorang pendidik profesional tentunya guru dituntut mempunyai rancangan-rancangan strategi dan juga metode-metode yang bermacam-macam untuk diterapkan dalam proses pembelajaran baik dalam pembelajaran umum maupun keagamaan, karena dari segi kecerdasan siswa yang tidak mungkin sama satu sama lain tentunya guru juga harus mempunyai cara agar apa yang disampaikan terkait materi pelajaran bisa sampai kepada siswa dan 
dapat dipahami oleh seluruh siswa, dengan menerapkan sebuah strategi yang cocok tentunya hal itu akan menjadi sarana tercapainya tujuan belajar.

Hasil dari wawancara dengan kepala sekolah dan guru pengampu pelajaran PAI yang peneliti kumpulkan, peneliti juga menambahkan data dengan mewawancarai beberapa siswa kelas X MIPA 1 pada tanggal 25 April 2019. Dalam wawancara dengan beberapa siswa peneliti menanyakan terkait penerapan strategi information search ynag diberikan oleh guru PAI, dalam wawancara para siswa mempunyai jawaban yang sama.

Salah satu siswa yang peneliti wawancarai mengungkapkan pendapatnya tentang penerapan strategi information search dengan mengoptimalkan penggunaan smartphone dalam sebuah pembelajaran PAI ini sangat efektif mengingat di zaman ini apapun bisa dicari dengan mudah di internet, bahkan ilmu pendidikan juga bisa searching dengan mudah tentu hal ini meciptakan kesenangan tersendiri bagi siswa yang belajar namun tetap mengoprasikan handphone dan imternet. Implementasi startegi information search yang diketahui para siswa secara umum mencari informasi terkait materi hanya menggunakan buku dan dokumen yang berbentuk kertas namun dalam strategi yang diterapkan oleh pendidik ini memanfaatkan kecanggihan teknologi yang mengaplikasikan metode pembelajaran dengan internet, para siswa mengungkapkan sangat senang karna pembelajaran tidak membosankan dan mereka juga merasa menjadi lebih aktif dalam menjelaskan tugas untuk lebih pandai dalam berpendapat.

Dan dalam ketiga hasil wawancara terkait pengimplementasian strategi information search ini peneliti mendapat kesimpulam bahwa penerapan strategi ini dalam pembelajaran PAI sangat bagus dan dapat mengoptimalkan penggunaan smartphone dalam pembelajaran sebagai sebuah media, karena dengan strategi aktif semacam ini dapat meningkatkan keaktifan siswa dalam proses pembelajaran seperti mempresentasikan tanggapan dalam mengamati tampilan video ataupun dalam memberikan keterangan terkait hafalan ayat-ayat yang menyangkut materi 
PAI dan hal ini sesuai dengan kurikulum 2013 yang mengharuskan siswa lebih aktif dalam pembelajaran.

Saat ini siswa SMA Negeri 1 Genteng berjumlah 1.071 orang. Mayoritas siswa berasal dari Kabupaten Banyuwangi dan beberapa siswa berasal dari Kabupaten sekitarnya seperti Kabupaten Jember, Kabupaten Jembrana Bali. Sebagian besar siswa bertempat tinggal lebih dari radius 5-10 km dari sekolah yang merupakan daerah perkampungan. Siswa yang masuk ke SMA Negeri 1 Genteng berasal dari SMP Negeri maupun Swasta, serta Sekolah Tsanawiyah (MTs).

Dengan adanya strategi pembelajaran Information seach merupakan sarana guru dalam meningkatkan minat siswa di dalam kelas. Dimana Information search merupakan salah satu metode pembelajaran kurikulum 2013. Siswa di tuntut lebih aktif dalam proses pembelajaran yaitu mencari informasi sesuai topik pembelajaran dari berbagai sumber seperti buku panduan pembelajaran, internet dan arike-artikel. Strategi ini memanfaatkan media smartphone sebagai sarana dalam pembelajaran PAI dimana siswa dapat mencari informasi yang dibutuhkan terkait materi pembelajaran PAI yang diberikan oleh guru, informasi yang mereka cari haruslah berlandaskan pada jurnal-jurnal PDF dan juga video yang berdurasi pendek. Kondisi siswa kelas X MIPA 1 yang berjumlah 37 siswa dan siswi saat pembelajaran PAI dengan strategi information search yang memanfaatkan media smartphone mampu meningkatkan cara berfikir dan belajar siswa menjadi lebih kritis dalam menangapi materi dan proses pembelajaran menjadi lebih aktif, kondusif dan kelas tidak gaduh.

Dengan adanya fasilitas sekolah seperti wifi dapat dimanfaatkan untuk siswa untuk penerapan strategi Information search. Karena dalam strategi pembelajaran Information search siswa menggunakan smartphone untuk mencari informasi mengenai topik pembelajaran seperti halnya mencari materi dalam proses pembelajaran yang berkaitan dengan Haji dan Umroh. Maka disinilah wifi sebagai faktor penunjang dan pendukung keberhasilan siswa, serta kepemilikan 
smartphone oleh siswa yang juga menjadi pendukung diterapkannya strtegi ini. Dan dengan ini efektifitas siswa dalam pembelajaran meningkat terbukti dengan antusias siswa saat pembelajaran.

Berdasarkan wawancara dan observasi yang peneliti lakukan pada pembelajaran PAI yaitu pada materi Haji dan Umroh siswa dituntut untuk memahami materi tersebut karena dalam Haji dan Umroh terdapat bacaan ayatayat dan gerakan yang harus di hafal juga di mengerti oleh siswa, maka dengan diterapkannya strategi information serach siswa dapat mencari ayat-ayat dan juga video yang berdurai pendek terkait materi Haji dan Umroh sehingga siswa mampu memahami serta menghafal ayat-ayat bacaan dan juga gerakan dalam ibadah Haji.

Pada proses pelaksanaan pembelajaran Pendidikan Agama Islam, dalam penyampaian materi ada tiga tahapan yang dilakukan oleh guru yaitu kegiatan awal berupa pendahuluan, kegiatan inti dan kegiatan akhir berupa penutup.

Dari hasil penelitian terbukti bahwa penerapan strategi information serach dengan mengoptimalkan penggunaan smartphone dalam pembelajaran PAI pada kelas X MIPA 1 SMA Negeri 1 Genteng memang mampu meningkatkan cara berfikir siswa dalam menanggapi suatu materi PAI hal ini terbukti dari cara siswa memberikan tanggapan terhadap tampilan video serta siswa mampu menghafal ayat-ayat dengan lebih lancar dan hal ini menjadi sebuah penunjang meningkatnya nilai pada setiap siswa.

Bukan tanpa kendala, dalam penerapan strategi information search dalam dengan mengoptimalkan penggunaan smartphone pada pembelajaran PAI guru pengampu juga kerapkali mendapati beberapa kendala dalam penerapan strategi ini, diantaranya : 1) Siswa yang cenderung mudah gaduh; 2) Terbatasnya jam mata pelajaran; 3) Siswa yang hanya mengandalkan teman lain dalam kelompok; 4) Internet yang bermasalah, beberapa hal yang disebutkan oleh guru PAI menjadi faktor penghambat yang perlu diantisipasi oleh guru supaya dapat menyiapkan solusi untuk hal tersebut. Namun dalam hal ini guru PAI menyampaikan dalam 
wawancara bahwa beliau selalu menyiapkan solusi untuk mengatasi kendalakendala yang terjadi dalam proses penerapan strategi ini.

Maka untuk menangani kendala-kendala yang dialami dalam proses pembelajaran PAI dengan menerapkan strategi information search ini guru PAI menjelaskan dalam wawancara dengan peneliti, yaitu :

1. Siswa yang gaduh

Guru menyetarakan ritme perintah untuk memulai proses pembelajaran dengan strategi information search.

2. Terbatasnya jam mata pelajaran (durasi waktu)

Guru memberikan aturan waktu durasi untuk setiap kelompok yang akan berpersentasi di depan kelas, jadi guru dapat mengkondisikan waktu yang sesuai untuk beberapa kelompok sehingga proses pembelajaran akan mecapai target pertemuan yang ditentukan dan berpatokan pada RPP.

3. Siswa yang hanya mengandalkan teman lain dalam kelompok.

Guru PAI akan membagi tugas pada setiap siswa dalam kelompok untuk menyampaikan hasil pemikirannya di depan kelas terkait perintah yang diberikan misalkan, menanggagi sebuah video yang berdurasi pendek tentang materi sejarah yaitu film peperangan pada zaman nabi, maka siswa akan mencari jawaban dan mengerjakan tugas yang nantinya akan dia persentasikan dalam satu kelompok.

4. Internet yang bermasalah

Mencari informasi terkait terjadinya kendala internet tersebut dan kemudian menggunakan strategi-strategi pembelajaran yang lain supaya perhatian siswa tetap difokuskan pada kegiatan pembelajaran misalkan dengan menampilkan video pendek tentang peperangan yang kemudian setiap kelompok harus memberikan tanggapan dan mempresentasikannya di depan, dengan cara ini siswa tetap dalam pembelajaran dan tetap dengan tujuan yang sama yakni mencari informasi. 
Dari penjelasan tersebut maka dalam penerapan strategi information serach dengan mengoptimalkan penggunaan smartphone pada pembelajaran PAI guru mempunyai peran sebagai pemimpin proses pembelajaran sehingga segala kendala yang dapat menghambat proses pembelajaran adalah menjadi tanggung jawab guru untuk memberikan solusi, supaya pembelajaran menjadi lebih efektif dan efisien serta dapat berjalan sebagaimana mestinya.

\section{Simpulan}

Bahwa penerapan strategi information search merupakan salah satu strategi pembelajaran kurikulum 2013. Dimana pada kelas X MIPA 1 dengan penerapan strategi Information search yang memanfaatkan media smartphone siswa lebih aktif dalam pembelajaran dan lebih kritis dalam menangapi materi karena dengan penerapan strategi Information search materi lebih dapat dipahami siswa dibandingkan dengan metode cramah, siswa juga sangat antusias karena siswa dapat mencari informasi sesuai topik pembelajaran dengan menggunakan media smartphone dari sumber-sumber mana saja yang jelas dan dapat dipertanggung jawabkan serta mengemukakan jawabannya dengan berdiskusi pada kelompoknya

Bahwasanya Strategi Information search dapat meningkatkan efektifitas proses pembelajaran PAI serta mampu meningkatkan cara berfikir siswa menjadi lebih kritis, siswa juga mampu memahami materi dengan mudah dan lebih lancar dalam menghafalkan ayat-ayat yeng menyangkut materi PAI.

Yang menjadi faktor pendukung dalam pengimplementasian strategi information search dengan mengoptimalkan penggunaan smartphone adalah antusias siswa itu sendiri, tersedianya jaringan wifi sekolah dan tentunya kepemilikan smartphone siswa, maka inilah yang menjadi penunjang sekaligus pendukung diimplementasikannya strategi information search dengan mengoptimalkan penggunaan smartphone dalam pembelajaran PAI.

\section{Daftar Rujukan}

Daulay, Haidar Putra. (2004). Pendidikan Islam dalam Sistem Pendidikan Nasional di Indonesia. Jakarta : Kencana

Mulyono, dan Ismail Suardi Wekke. (2018). Strategi Pembelajaran di Abad Digital. Yogyakarta : Adi Karya Mandiri 
Nainggolan, John M. (2008). Strategi Pendidikan Agama Kristen. Jakarta : Infomedia

Nata, Abuddin. (2015). Studi Islam Komprehensif. Jakarta : Prenada Media.

Pamungkas, Pipin Santi. (2014). Penerapan Strategi Berburu Informasi Dalam Rangka Meningkatkan Pemahaman Tentang Kegiatan Ekonomi Di Indonesia Pada Mata Pelajaran Ips Siswa Kelas V MI Bahrul Ulum MengantiGresik. Skripsi. Yogyakarta : Fakultas Tarbiyah dan Keguruan Universitas Islam Negeri Sunan Kalijaga Yogyakarta.

Prasojo, Diat Lantip, Riyanto. (2011). Teknologi Informasi Pendidikan Yogyakarta: Gava Media

Rusman. (2012). Model-Model Pembelajaran Mengembangkan Profesional Guru. Jakarta: Rajawali Pres

Rustaman. (2001). Inovasi Baru Kurikulum 2013 1Pendidikan Agama Islam Dan Budi Pekerti.Yogyakarta :Deepublish.

Sagala, Syaiful. (2003). Konsep Dan Makna Pembelajaran. Bandung : Alfabeta.

Salim, Peter dan Salim, Yeni. (1991). Kamus Bahasa Indonesia Kontemporer, Jakarta : Modern Press.

Sanjaya, Wina. (2009). Strategi Pembelajaran Berorientasi Standar Proses Pendidikan.Jakarta: Prenada.

Siagian, Sondang P.. (2014). Ilmu dan Aplikasi Pendidikan. Jakarta : Grasindo.

Sugiyono. (2008). Metode Penelitian Pendidikan. Bandung :Alfabeta

Tina, Aprian. (2018). Jurnal Skripsi Pengaruh Strategi Informastion Search Terhadap Penguasaan Konsep.Skripsi.Universitas Islam Negeri Raden Intan Lampung.

Triwibowo. (2015). Deskripsi Efektifitas Discovery Learning Pada Pembelajaran Matematika di SMP Muhammadiyah 5 Purbalingga.Skripsi. Purwokerto : Fakultas Keguruan dan Ilmu Pendidikan Islam Universitas Muhammadiyah 
Nur Laela Dewi, Ahmad Izza Muttaqin \& Al Muftiyah

Waluyo, Edi. (2011). Pengaruh Aktivitas Guru dan Motivasi Belajar Siswa.

Skripsi.Yogyakarta : Jurusan Tarbiyah Universitas Negeri Yogyakarta

Wijaya, Iwan. (2018). Professional Teacher :Menjadi Guru Profesional. Sukabumi : Jejak Publisher.

Winarno, Budi. (2008). Kebijakan Publik : Teori dan Proses.Yogyakarta : Media Pressindo.

Zaini, Hisyam. (2002). Strategi Pembelajaran Aktif di Perguruan Tinggi. Bandung, : CTSD.

Zaini, Hisyam dkk. (2008). Strategi Pembelajran Aktif. Yogyakarta : CTSD 